JUAN ALCÁNTARA

\title{
LA TORRE
}

\author{
somos una torre soy \\ una torre \\ camino \\ como una torre \\ rígido a punto \\ de caer \\ y destrozarme \\ la vista cuadrada \\ por el ventanal \\ las manos atadas \\ cargados \\ los flancos \\ soy una torre somos \\ una torre \\ tengo que construirla \\ para abandonarla \\ miro una flor \\ desde el piso cincuenta \\ las nubes \\ desde el piso cuarto \\ camino con los dedos \\ en el vasto jardín \\ que no tengo \\ (ningún árbol sube o \\ baja hasta aquí)
}




\author{
soy una torre me \\ voy construyendo yo \\ quisiera ser un \\ peatón \\ con una mano me rasco el \\ pararrayos \\ con la otra me aprieto \\ el cimiento \\ todos los días subo \\ por los andamios \\ caigo \\ por los desechaderos
}

y cuando quede la torre

quién

me asegura

quién

que yo quede afuera?

no sé si es un pozo o una torre

lo que construyo

por las tardes me

duele la luz 